\title{
MANAGEMENT
FORUM
}

Publishing House of Wrocław University of Economics

\section{Odnowa modelu biznesu}

\section{Business model renewal}

\author{
Tadeusz M. Falencikowski \\ Politechnika Gdańska, e-mail: tadeusz.falencikowski@gmail.com
}

\begin{abstract}
Streszczenie
Celem prac było scharakteryzowanie węzłowych problemów warunkujących odnowę modelu biznesu. Do nich zaliczono ujęcie definicji i struktury modelu biznesu, zarysowanie pojęcia jego odnowy i jej uwarunkowań. Nakreślono ciąg zarządzania strategicznego w przedsiębiorczym procesie powstawania biznesu: pomysł na biznes, model biznesu i strategia biznesu. Pozwoliło to na umiejscowienie modelu biznesu oraz wskazanie kluczowych uwarunkowań odnowy w postaci redefinicji pomysłu na biznes, a zwłaszcza wartości tam generowanych. W pracach innych badaczy na uwagę zasługuje redefinicja wartości dla klientów i nie-klientów, stanowiąca podstawę innowacyjności modeli biznesu. Pozwoliło to na sformułowanie zdania, że odnowę modelu biznesu należy prowadzić w bardziej holistycznym ujęciu. W zakresie odnowy polskich przedsiębiorstw zajęto stanowisko, że należy ją oprzeć na rewitalizacji wszystkich składników ciągu zarządzania strategicznego biznesem, a początkiem musi być rewitalizacja pomysłu na biznes.
\end{abstract}

Słowa kluczowe: model biznesu, odnowa modelu biznesu, innowacyjność modelu biznesu, odnowa organizacyjna.

\section{Abstract}

The aim of this study is to characterize the nodal problems determining the renewal of business model. These problems included a definition and structures of the business model, outlining the concept of its renewal and conditions which then occurred. A sequence of strategic management in the entrepreneurial process of business formation including: business idea, business model and business strategy was identified. This allowed for the location of the business model in that sequence and identified a key renewal determinant as to redefine the business idea, and especially the value generated there. The analysis of previous work in the field of innovation of business models enabled the formulation of the questions that other researchers worked on and the identification of the results which they achieved. Particularly noteworthy in this regard is the transformation of value for customers and the regeneration of new values for non-customers, which will be the basis of business models innovation. On that basis a sentence was formulated that the renewal of business model should be carried out in a more holistic approach. It was considered that the renewal of Polish enterprises should be based on the revitalization of all components within the strategic management of business, and the revitalization of business idea had to be the beginning.

Keywords: business model, renewal of business model, innovation of business model, organizational renewal. 


\section{Wstęp}

Powstanie biznesu ${ }^{1}$ jest efektem aktywności przedsiębiorcy, która ma co najmniej dwa oblicza. Pierwsze z nich to aktywność konceptualna. Można wyróżnić dwa jej efekty - przedsiębiorca na podstawie obserwacji, własnego rozumienia otoczenia i chęci zmiany świata na lepsze tworzy pomysł na biznes oraz konstruuje obraz owego biznesu jako organizacji w ujęciu atrybutowym. Ów obraz jest zwykle nieco uproszczony, ma bowiem przedstawiać logikę tego biznesu, a zatem opisywać istotę wytwarzanych produktów, sposób ich wytwarzania oraz wynagrodzenie przedsiębiorcy z tego tytułu. Ujęcie istoty wytwarzanych produktów musi odpowiedzieć na pytanie, jakie potrzeby klientów będą zaspokajane. Ponieważ zaspokojenie owych potrzeb jest wartością dla klienta, przeto de facto formułuje się zdanie o postaci owych wartości. Sposób wytwarzania produktów ujmuje technikę i technologię wytwarzania. Natomiast opis wynagrodzenia przedsiębiorcy zawiera poglądy o istocie finansowej i społecznej podejmowanego biznesu. Drugie oblicze to przechodzenie aktywności konceptualnej w aktywność czynnościową - przedsiębiorca gromadzi materialne i niematerialne zasoby oraz kompetencje, a także zawiązuje między nimi relacje aktywności wytwórczej. Zbiory zgromadzonych zasobów, kompetencji i relacji muszą posiadać cechy konieczne i wystarczające do realizacji funkcji genotypowej. Następnie przedsiębiorca uruchomia procesy wytwórcze, w wyniku których uzyskuje produkt. Zbycie tego produktu wymaga zaplanowania i wdrożenia strategii konkurencyjnej, ponieważ bez wygrania walki z innymi podmiotami zbywającymi wyroby ${ }^{2}$ przedsiębiorca nie sprzeda swoich produktów. Przy planowaniu strategii konkurencji przedsiębiorca szacuje ryzyko biznesu i do niego konfiguruje instrumenty konkurowania.

Na podstawie sformułowanego tutaj opisu można wyłonić trzy główne składniki procesu tworzenia biznesu, tj. pomysł na biznes, ujęty atrybutowo obraz biznesu oraz strategię konkurencji. W tej triadzie erygowania biznesu trzeba jeszcze doprecyzować drugi składniki. Otóż ujęty atrybutowo obraz biznesu, opisujący w sposób uproszczony jego logikę, jest określany mianem modelu biznesu. Opisany tutaj proces tworzenia biznesu można przedstawić graficznie (rys. 1).

Sformułowane na wstępie komponenty biznesu (rys. 1) mają wymiar strategiczny, ich kształty wywołują bowiem skutki w całym czasie trwania biznesu. Nie oznacza to, że są niezmienne. Zmiana uwarunkowań prowadzenia biznesu, a zwłaszcza zmiana potrzeb klientów powoduje, że treść komponentów biznesu ulega wyczerpaniu. Zatem w celu kontynuowania działalności gospodarczej menedżerowie muszą poddawać komponenty biznesu odnowie. Na podstawie rys. 1 można zauważyć, że kluczową rolę w tej rewitalizacji odgrywa model biznesu.

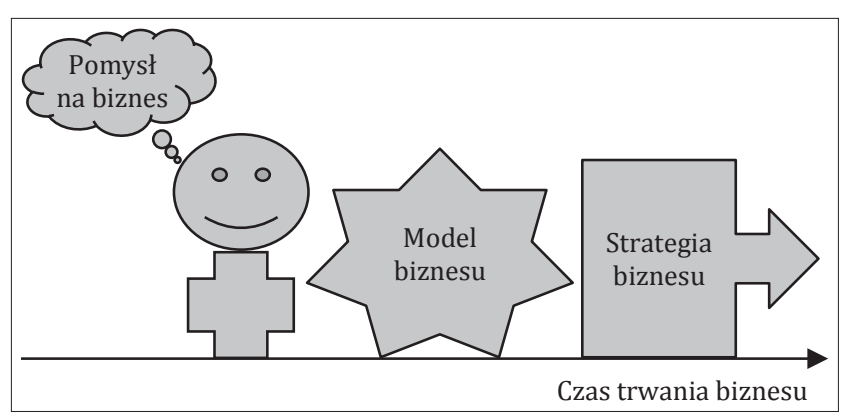

Rysunek 1. Składniki ciągu zarządzania strategicznego $\mathrm{w}$ przedsiębiorczym procesie powstawania biznesu

Źródło: opracowanie własne.

W tym świetle celem niniejszej pracy jest opisanie węzłowych zagadnień odnowy modelu biznesu. Praca ma charakter teoretyczny i jest oparta na krytycznej analizie literatury opisującej istotę modelu biznesu oraz odnowę przedsiębiorstw. Ponadto w pracy wykorzystano indukcyjne i dedukcyjne metody wnioskowania i formułowania zdań orzekających.

W drodze do osiągnięcia celu pracy została podjęta próba sformułowania definicji i struktury modelu biznesu, nakreślono pojęcia jego odnowy i występujących przy tym niektórych uwarunkowań.

\section{Istota modelu biznesu}

We wstępie wskazano, że podstawową funkcją modelu biznesu jest formułowanie uproszczonego opisu logiki prowadzenia biznesu. Aby model biznesu temu podołał, trzeba definicyjnie ująć istotę oraz określić jego strukturę.

W świetle określonej wyżej funkcji niemała grupa badaczy podejmowała próbę zdefiniowania pojęcia 'model biznesu'. Niektóre z tych prób zawarto w tab. 1, a wyboru definicji dokonano tak, aby ująć chronologiczny przebieg tego procesu.

Na podstawie analizy definicji zawartych $\mathrm{w}$ tab. 1 i pewnego zbioru literatury oraz własnego rozumienia omawianego fenomenu sformułowano pogląd, że model biznesu to wieloskładnikowy obiekt konceptualny opisujący prowadzenie biznesu, poprzez artykułowanie logiki tworzenia wartości dla klienta i przechwytywania części tej wartości przez przedsiębiorstwo [Falencikowski 2013, s. 37]. Przedstawiona tutaj definicja pozwala wyłonić:

- podstawową osnowę modelu biznesu - tworzenie wartości,

- $\quad$ wymiary modelu biznesu - to dwa główne składniki tworzonych wartości. Pierwszy z nich to wartość dla klienta, drugi zaś stanowi wartość dla przedsiębiorstwa.

\footnotetext{
${ }^{1}$ Biznes jest tu rozumiany jako jednorodna przedmiotowo działalność gospodarcza.

${ }^{2}$ Wygranie walki konkurencyjnej z innymi podmiotami gospodarczymi zbywającymi swoje produkty nie ogranicza się tylko do rywalizacji w danej branży. Obejmuje również rywalizację międzybranżową, bowiem aby nabywca kupił dany produkt, musi dokonać ograniczenia wydatków przy nabywaniu innych produktów.
} 
Tabela 1. Zbiór definicji modelu biznesu

\begin{tabular}{|c|c|c|c|}
\hline Lp. & Treść definicji & Składniki modelu biznesu & Źródło \\
\hline 1 & $\begin{array}{l}\text { Model biznesu określa podejście organizacji do generowania } \\
\text { dochodu w sensownym koszcie i wciela założenia o tworzeniu } \\
\text { i schwytaniu wartości }\end{array}$ & $\begin{array}{l}\text { Dochód } \\
\text { Koszty } \\
\text { Tworzenie wartości } \\
\text { Przejmowanie wartości }\end{array}$ & $\begin{array}{l}\text { A. Brandenburger, } \\
\text { S.H. Stuart } \\
{[1996]}\end{array}$ \\
\hline 2 & $\begin{array}{l}\text { Model biznesu to powiązana z klientami kompozycja kluczowej } \\
\text { strategii, strategicznych zasobów oraz sieci wartości }\end{array}$ & $\begin{array}{l}\text { Wymiary modelu biznesu: } \\
\text { - wydajność } \\
\text { - niepowtarzalność } \\
\text { - dopasowanie } \\
\text { - akceleratory dochodu } \\
\text { Składniki modelu biznesu: } \\
\text { - logika klienta, } \\
\text { - obsługa klientów, } \\
\text { - informacja i wyprzedzenie } \\
\text { - racjonalna dynamika } \\
\text { - struktura cen } \\
\text { - cel strategii } \\
\text { - produkty i segmenty rynku } \\
\text { - różnicowanie w relacji do konkurentów } \\
\text { - zasoby i umiejętności } \\
\text { - zasoby strategiczne } \\
\text { - metodologia procesów wytwórczych } \\
\text { - sieci: dostawców, partnerów, aliansów }\end{array}$ & $\begin{array}{l}\text { G. Hamel } \\
{[2000, \text { s. } 74]}\end{array}$ \\
\hline 3 & $\begin{array}{l}\text { Model biznesu przedstawia istotę, strukturę i kierowanie } \\
\text { transakcjami, aby kreować wartość przez wykorzystanie okazji } \\
\text { biznesowych }\end{array}$ & $\begin{array}{l}\text { Elementy projektowania opisują architekturę systemu działalności - } \\
\text { zawartość (dobra i informacje), struktura (związki między interesariuszami) } \\
\text { i kierowanie (kontrola strumieni dóbr, informacji i zasobów). } \\
\text { Tematy projektowania opisują źródła tworzenia wartości: nowość, blokada } \\
\text { konkurentów, komplementarność i wydajność. }\end{array}$ & $\begin{array}{l}\text { R. Amit, C. Zott } \\
{[2001 ; 2010 ;} \\
2012]\end{array}$ \\
\hline 4 & $\begin{array}{l}\text { Model biznesu jest konceptualnym narzędziem wyrażającym } \\
\text { biznesową logikę firmy i zawierającym zbiór przedmiotów, pojęć i ich } \\
\text { relacji z celem.Ujmuje on opis: wartości skierowanej do jednego lub } \\
\text { kilku segmentów klientów, architektury firmy, sieci partnerów } \\
\text { w tworzeniu wartości, sposobów dostarczania wartości, kapitału } \\
\text { relacyjnego i zrównoważonych strumieni dochodów. }\end{array}$ & $\begin{array}{l}\text { Propozycja wartości } \\
\text { Docelowy klient } \\
\text { Kanały dystrybucji } \\
\text { Relacje z klientami } \\
\text { Konfiguracja wartości } \\
\text { Rdzenne kompetencje } \\
\text { Model zarządzania } \\
\text { Sieć partnerów } \\
\text { Struktura kosztów } \\
\text { Model dochodów }\end{array}$ & $\begin{array}{l}\text { A. Osterwalder, } \\
\text { Y. Pigneur, } \\
\text { C.L. Tucci } \\
{[2005]}\end{array}$ \\
\hline 5 & $\begin{array}{l}\text { Model biznesu to ogólna koncepcja, formułująca ramy logiki } \\
\text { prowadzenia biznesu i takich jego cech, jak innowacyjność czy } \\
\text { konkurencyjność. }\end{array}$ & \begin{tabular}{|l|} 
Wartość oferowana klientom \\
Podstawowe zasoby i działania \\
Relacje z partnerami
\end{tabular} & $\begin{array}{l}\text { B. Nogalski } \\
{[2009]}\end{array}$ \\
\hline 6 & $\begin{array}{l}\text { Model biznesu racjonalnie opisuje, jak organizacja tworzy, } \\
\text { dostarcza i przechwytuje wartość. }\end{array}$ & $\begin{array}{l}\text { Segmenty klientów } \\
\text { Propozycja wartości } \\
\text { Kanały dystrybucji } \\
\text { Relacje z klientami } \\
\text { Strumienie dochodów } \\
\text { Kluczowe zasoby } \\
\text { Kluczowe aktywności } \\
\text { Kluczowi partnerzy } \\
\text { Struktura kosztów } \\
\end{array}$ & $\begin{array}{l}\text { A. Osterwalder, } \\
\text { Y. Pigneur } \\
{[2010, \text { s. } 14]}\end{array}$ \\
\hline 7 & $\begin{array}{l}\text { Model biznesu oddaje logikę tworzenia i dostarczania wartości } \\
\text { klientom przez biznes. Określa też architekturę dochodów, } \\
\text { kosztów i korzyści związanych z biznesowym przedsięwzięciem } \\
\text { dostarczającym tę wartość. } \\
\text { Model biznesu definiuje, jak przedsiębiorstwo tworzy i dostarcza } \\
\text { wartość klientom i jak przemienia otrzymywane wynagrodzenie } \\
\text { na zysk. }\end{array}$ & $\begin{array}{l}\text { Docelowy segment rynku } \\
\text { Korzyści dla klienta (użyte produkty i usługi) } \\
\text { Technologie i cechy produktów/usług } \\
\text { Mechanizm przechwycenia wartości } \\
\text { Podtrzymanie strumieni osiąganych dochodów }\end{array}$ & $\begin{array}{l}\text { D.J. Teece } \\
{[2010]}\end{array}$ \\
\hline 8 & $\begin{array}{l}\text { Model biznesu określa logikę powiązań zawiązujących się } \\
\text { pomiędzy zasobami, będącymi w dyspozycji organizacji, } \\
\text { a działaniami tworzącymi wartość dla szeroko rozumianych } \\
\text { klientów. }\end{array}$ & $\begin{array}{l}\text { Domena działalności } \\
\text { Propozycja wartości } \\
\text { Kanały dystrybucji } \\
\text { Relacje z klientami } \\
\text { Strumienie przychodów } \\
\text { Kluczowe zasoby } \\
\text { Kluczowe działania } \\
\text { Kluczowi partnerzy } \\
\text { Struktura kosztów } \\
\end{array}$ & $\begin{array}{l}\text { Sz. Cyfert, } \\
\text { K. Krzakiewicz } \\
{[2011,} \\
\text { s. } 100-105]\end{array}$ \\
\hline 9 & $\begin{array}{l}\text { Model biznesu konstytuuje się poprzez połączenie czterech } \\
\text { składników: propozycji wartości dla klienta, formuły zysków, } \\
\text { kluczowych procesów i zasobów. }\end{array}$ & $\begin{array}{l}\text { Propozycja wartości dla klienta } \\
\text { Formuła zysków } \\
\text { Kluczowe procesy } \\
\text { Kluczowe zasoby }\end{array}$ & $\begin{array}{l}\text { M.J. Eyring } \\
\text { M.W. Johnson, } \\
\text { H. Nair } \\
{[2012]} \\
\end{array}$ \\
\hline 10 & $\begin{array}{l}\text { Model biznesu to postrzegana przez menedżerów logika tworzenia } \\
\text { wartości w związku z otoczeniem rynkowym oraz w ramach } \\
\text { przedsiębiorstwa }\end{array}$ & $\begin{array}{l}\text { Tworzone wartości } \\
\text { Kluczowe produkty }\end{array}$ & $\begin{array}{l}\text { J. Aspara, } \\
\text { J.A. Lamberg, } \\
\text { A. Laukia, } \\
\text { H. Tikkanen } \\
\text { [2013] }\end{array}$ \\
\hline
\end{tabular}

Źródło: opracowanie własne na podstawie cytowanych źródeł oraz [Falencikowski 2013]. 


\section{Struktura modelu biznesu}

W tabeli 1 zawarto składniki, z których wymienieni badacze konstruują modele biznesów. Ich przegląd pozwala wskazać, że u wszystkich autorów występuje różnie ujmowana propozycja wartości dla klienta oraz zasoby. Często pojawiają się kluczowe procesy lub działania, a co do innych składników już pełnej zgody nie ma.

W ostatnich czterech latach pewną popularność zdobył model biznesu opracowany przez A. Osterwaldera i Y. Pigneura, a opublikowany w pracy z 2010 roku. Jego poprzednikiem był model z 2005 roku, ich porównanie zawarto w tab. 2.

Tabela 2. Porównanie składników dwóch modeli biznesu

\begin{tabular}{l|l}
$\begin{array}{c}\text { Składniki modelu } \\
\text { biznesu autorstwa: } \\
\begin{array}{c}\text { A. Osterwalder, Y. Pigneur, C. L. Tucci } \\
{[2005]}\end{array}\end{array}$ & $\begin{array}{c}\text { Składniki modelu } \\
\text { biznesu autorstwa: } \\
\text { A. Osterwalder, Y. Pigneur } \\
{[2010, \text { s. 14] }}\end{array}$ \\
\hline Docelowy klient & Segmenty klientów \\
\hline Propozycja wartości & Propozycja wartości \\
\hline Konfiguracja wartości & \\
\hline Kanały dystrybucji & Kanały dystrybucji \\
\hline Relacje z klientami & Relacje z klientami \\
\hline Rdzenne kompetencje & $\begin{array}{l}\text { Kluczowe aktywności } \\
\text { Kluczowe zasoby }\end{array}$ \\
\hline Sieć partnerów & Kluczowi partnerzy \\
\hline Model dochodów & Strumienie dochodów \\
\hline Struktura kosztów & Struktura kosztów \\
\hline Model zarządzania & \\
\hline Zró
\end{tabular}

Źródło: opracowanie własne.

Analiza porównawcza danych zawartych $\mathrm{w}$ tab. 2 pozwala wyłonić różnicę parametryczną: model biznesu z 2005 roku zawierał 10 składników, a ten z 2010 roku został zbudowany z 9 elementów. Następna różnica polega na tym, że w konstrukcji z 2010 roku nie występują model zarządzania oraz konfiguracja wartości. Kolejna to dezagregacja rdzennych kompetencji na kluczowe aktywności i zasoby. Na występujące różnice być może wpływ wywarło to, że model z 2005 roku posiadał trzech autorów, a w 2010 roku było ich dwóch.

Ponadto można zauważyć, że niektóre składniki w omawianym modelu charakteryzują się nadmiernym rozdrobnieniem. W tym zakresie można wskazać, że po pierwsze: segmenty obsługiwanych klientów, relacje z klientami oraz propozycja wartości kluczowe to w rzeczywistości jeden segment obejmujący generowanie wartości dla klienta; po drugie elementy: strumienie dochodów oraz struktura kosztów ujmują de facto mechanizm przechwytywania wartości dla przedsiębiorstwa, i to tylko wartości ekonomicznych, podczas gdy w biznesie generuje się także inne grupy wartości, jak np. wartości emocjonalne, użytkowe i inne; po trzecie składniki: kluczowe zasoby i kluczowi partnerzy w istocie współtworzą jeden segment zasobowy.

Omawiana tutaj konstrukcja charakteryzuje się jeszcze dwiema słabościami. Pierwsza z nich to brak powiazań składników ze sobą i z otoczeniem biznesu. W obecnym stanie ten model przypomina kości do gry wrzucone do kubełka, które przy poruszeniu swobodnie grzechoczą! Nadto nie widać ich powiązań z otoczeniem - to tak, jakby ów kubek izolował kości od otoczenia. Druga to całkowite pominięcie kwestii konkurencji. Samo wytworzenie produktu i osadzenie na nim wartości nie zapewnia sprzedaży. Aby zbyć produkt, trzeba zastosować sytuacyjnie dobrane instrumenty konkurowania.

Mając na uwadze poczynione uwagi oraz istniejący stan wiedzy w omawianym zakresie, podjęto działania zmierzające do zaproponowania własnego modelu biznesu. Jednakże zanim zostanie on przedstawiony, konieczne jest poczynienie uwag dotyczących celu budowy modelu biznesu. Kariera modeli biznesu związana jest $\mathrm{z}$ ich wykorzystaniem $\mathrm{w}$ prospektach emisyjnych na giełdzie papierów wartościowych w trakcie trwania tzw. bańki dot.comów w USA (lata 2001/2002). Załamanie notowań przedsiębiorstw typu dot.com spowodowało krytykę wartości modelu biznesu. Z tego można wyprowadzić wniosek, że modele biznesu mogą być formułowane w celach utylitarnych. Na inny cel budowy modelu biznesu wskazali C. Baden-Fuller i M.S. Morgan [2010]. Formułując typologię modeli biznesów, ujęli oni modele skali i modele roli, zaznaczając, że każdy model może być budowany w celach naukowych, jednak wówczas musi spełniać określone wymagania. Mając to na uwadze, poniżej przedstawiono model biznesu sformułowany do celów naukowych. W konstrukcji tej zastosowano siedem elementów konstytuujących oraz dwie grupy związków łączących owe elementy w całość ze sobą i z otoczeniem biznesu. Proponowany model biznesu zawiera: wartości dla klienta, kompetencje, zasoby, łańcuch wartości, kanały dystrybucji, instrumenty konkurowania, wartości dla przedsiębiorstwa (na podstawie [Falencikowski 2014, s. 68]). Te siedem składników wiążą ze sobą w całość następujące związki wewnętrzne: przynależności celowej, kompatybilności, przystawania, zgodności wzajemnej i funkcjonalnej. Natomiast z otoczeniem składniki modelu biznesu łączą takie związki zewnętrzne, jak: zgodności celowej, podobieństwa, przyczynowo-skutkowe [Falencikowski 2013, s. 91]. Taki zbiór składników modelu biznesu, jak można sądzić, jest konieczny i wystarczający do opisania logiki prowadzenia biznesu.

Tak jak każdy model, również tutaj omawiany posiada określone uproszczenia. Wynikają one z celu formułowania modelu oraz z tego, że pełne odwzorowanie funkcjonowania biznesu nie jest uzasadnione sprawnością i efektywnością się nim posługiwania.

Podjęcie orzeczeń w zakresie ontologii modelu biznesu pozwala przejść do zagadnień jego odnowy, jak bowiem wspomniano na wstępie, sformułowane na początku działalności gospodarczej składniki ciągu zarządzania strategicznego biznesem [Falencikowski 2014] ujęte na rys. 1 nie są niezmienne.

\section{Pojęcie odnowy modelu biznesu}

Model biznesu, na co zwrócono uwagę przy jego definicji, opisuje tworzenie wartości dla klienta i przechwytywanie wartości dla przedsiębiorstwa. Dla biznesu zagadnieniem krytycznym jest adekwatność tworzonych i przechwytywanych wartości. Tworzenie wartości (np. użytkowych, wymiennych, technicznych, emocjonalnych etc.) dokładnie odpowiadających 
obecnym i przyszłym potrzebom klientów jest taką aktywnością, która w dużym stopniu może kształtować jedno z oblicz sukcesu. Przechwytywanie takich wartości, których oczekują interesariusze przedsiębiorstwa (np. emocjonalnych, ekonomicznych, społeczno-etycznych), może współtworzyć drugie oblicze sukcesu. Wymienione tutaj i inne wartości występujące w czasie prowadzenia biznesu ulegają zmianom, zmianie ulegają bowiem liczne potrzeby ludzi. Na tym oparty jest proces ustawicznej fluktuacji wartości w biznesie. Powstanie rozbieżności między wartościami tworzonymi w biznesie a oczekiwanymi przez interesariuszy jest podstawową kanwą konieczności dokonywania zmian w całym ciągu zarządzania strategicznego biznesem, a w tym rewitalizacji modelu biznesu. Z tego wynika, że odnowa modelu biznesu powinna być częścią (składnikiem) odnowy całej organizacji.

W naukach o zarządzaniu prowadzono prace obejmujące problem odnowy organizacyjnej ${ }^{3}$, a w tym m.in. zagadnienia ontologiczne, takie jak definiowanie tego pojęcia. Niektóre ze sformułowanych poglądów ujęto w tab. 3.

Na podstawie przedstawionych w tab. 3 definicji można sformułować kilka uwag. Po pierwsze, słusznie zwraca uwagę J. Karpacz, że istotą rewitalizacji jest odnowienie kluczowych idei. Bez nowego ideowego tchnienia biznes będzie, nawet po „liftingu”, przypominał starą, tylko odświeżoną karocę. Zatem, wykorzystując przedstawione definicje w sensie ogólnym, odnowa organizacyjna stanowi treść, proces i efekt przekształceń kluczowych elementów systemu zarządzania. Na tle tej definicji trzeba odnieść się do jej części składowych. 0 treści odnowy stanowi nowa idea biznesu. Proces odnowy został opisany przez Sz. Cyferta [2012] w ujęciu systemowym i zawiera fazy: definicyjną, regulacyjną oraz realizacyjną. Efekt odnowy sfor- mułował J. Karpacz [2011]: to najlepsze dopasowanie charakterystyk zasobów i kompetencji do szans i zagrożeń.

Przenosząc sformułowane tutaj wnioski na grunt modeli biznesu, można przyjąć, że odnowa modelu biznesu to treść, proces i efekt przekształceń jego kluczowych komponentów. 0 treści odnowy modelu biznesu decyduje rewitalizacja idei biznesu, a ta jest zawarta w pomyśle na biznes. $W$ tej sferze mogą wystąpić dwie sytuacje. Pierwsza - istota pomysłu na biznes pozostaje bez zmian, a zmianie ulegają tylko niezbędne elementy, np. do produkcji butów dla mężczyzn dodaje się produkcję butów dla kobiet. W takiej sytuacji mamy do czynienia z liftingiem biznesu, czyli w ujęciu aksjologicznym zmiany są nieduże, niezbyt gruntowne, dostosowawcze, transformujące wartości generowane w biznesie do wymagań rynku. Druga istota pomysłu na biznes ulega zmianie typu Schumpeterowskiego, zatem uderza w jego podstawy ${ }^{5}$, generując zbiór nowych wartości. Taka zmiana treści biznesu miała miejsce, gdy Apple wprowadziło na rynek tablety. Wymienione tutaj typy rewitalizacji pomysłu na biznes przekładają się na model biznesu poprzez generowane wartości. To one muszą ulec odnowie! Zatem treść odnowy modelu biznesu określana jest poprzez zamianę treści (rodzajów i jakości) wartości dla klienta.

Proces odnowy modelu biznesu ujmuje wysiłek konceptualny redefiniowania jego dotychczasowych składników i, w zależności od rodzaju treści odnowy, może mieć charakter transformacyjny lub inkrementalny. W pierwszym przypadku kluczowe cechy komponentów modelu biznesu pozostają bez istotnych zmian lub mają ograniczony zasięg, w drugim zaś produktom nadaje się nowe jakościowo wartości. Pewne dookreślenie kierunków zmian w procesie odnowy składników modelu biznesu zawarto $w$ tab. 4 .

Tabela 3. Zbiór definicji odnowy organizacyjnej i pojęć bliskoznacznych

\begin{tabular}{|c|c|c|}
\hline Lp. & Określenie & Źródło \\
\hline 1 & $\begin{array}{l}\text { Odnowa strategiczna to treść, proces i efekt przekształcania lub wymiany tych cech organizacji, które posiadają znaczący } \\
\text { wpływ na jej długofalowe funkcjonowanie. }\end{array}$ & $\begin{array}{l}\text { R. Agarwal, C. Helfat } \\
\text { [2009] }\end{array}$ \\
\hline 2 & $\begin{array}{l}\text { Strategiczne odnawianie jest to „przekształcanie organizacji przez odnowienie kluczowych idei, na bazie których jest ona } \\
\text { zbudowana”. } \\
\text { „Odnowa strategiczna potencjału przedsiębiorstwa oznacza przeprowadzenie zmian w celu jak najlepszego dopasowania } \\
\text { charakterystyk tworzących go zasobów materialnych i niematerialnych do warunków podyktowanych eksploatacją szans } \\
\text { oraz neutralizacją zagrożeń”. } \\
\text { Zmiana strategiczna to przekształcenie organizacji w obszarze sposobów wykorzystania posiadanych i przyszłych } \\
\text { zasobów. }\end{array}$ & $\begin{array}{l}\text { J. Karpacz } \\
{[2011, \text { s. 36-37] }}\end{array}$ \\
\hline 3 & $\begin{array}{l}\text { „Zmiana formuły działania organizacji, skutkująca rekonstrukcją modelu biznesu, określana jest mianem odnowy } \\
\text { organizacyjnej” }\end{array}$ & $\begin{array}{l}\text { Sz. Cyfert } \\
{[2012]}\end{array}$ \\
\hline 4 & „Odnowa przedsiębiorstwa to treść, proces i efekt przekształceń kluczowych elementów modelu biznesowego” & $\begin{array}{l}\text { G. Bełz } \\
{[2012]}\end{array}$ \\
\hline 5 & $\begin{array}{l}\text { „Zmiana formuły działania organizacji, skutkująca rekonstrukcją systemu zarządzania, jest określana mianem odnowy } \\
\text { organizacyjnej. [...] Odnowa organizacyjna stanowi treść, proces i efekt przekształceń kluczowych elementów systemu } \\
\text { zarządzania warunkowanych zmianami modelu biznesowego”. }\end{array}$ & $\begin{array}{l}\text { Sz. Cyfert, G. Bełz, } \\
\text { Ł. Wawrzynek } \\
{[2014]}\end{array}$ \\
\hline
\end{tabular}

Źródło: opracowanie własne.

\footnotetext{
${ }^{3}$ Nazywanej również odnową strategiczną lub odnową przedsiębiorstwa.

${ }^{4} \mathrm{~W}$ dalszej części pracy określana mianem odnowy transformującej.

${ }^{5}$ Dalej nazywane odnową inkrementalną.
} 
Tabela 4. Zmiana składników modelu biznesu w jego odnowie

\begin{tabular}{|c|c|c|}
\hline \multirow{2}{*}{$\begin{array}{l}\text { Nazwa składnika modelu } \\
\text { biznesu }\end{array}$} & \multicolumn{2}{|c|}{ Odnowa } \\
\hline & transformacyjna & inkrementalna \\
\hline $\begin{array}{l}\text { Wartości dla klienta: } \\
\text { - emocjonalne } \\
\text { - techniczne } \\
\text { - ekonomiczne } \\
\text { - społeczno-etyczne }\end{array}$ & $\begin{array}{l}\text { bez zmiany } \\
\text { mała zmiana } \\
\text { bez zamiany } \\
\text { mała zmiana }\end{array}$ & $\begin{array}{l}\text { duże zmiany } \\
\text { lub nowe wartości }\end{array}$ \\
\hline Kompetencje & mała zmiana & $\begin{array}{l}\text { duża zmiana } \\
\text { lub nowe } \\
\text { kompetencje }\end{array}$ \\
\hline Zasoby & $\begin{array}{l}\text { bez zmian lub } \\
\text { mała zmiana }\end{array}$ & $\begin{array}{l}\text { duża zmiana } \\
\text { lub nowe zasoby }\end{array}$ \\
\hline Łańcuch wartości & $\begin{array}{l}\text { bez zmian lub } \\
\text { mała zmiana }\end{array}$ & $\begin{array}{l}\text { nowy łańcuch } \\
\text { wartości }\end{array}$ \\
\hline Kanały dystrybucji & $\begin{array}{l}\text { bez zmian lub } \\
\text { mała zmiana }\end{array}$ & $\begin{array}{l}\text { duże zmiany } \\
\text { lub nowe kanały }\end{array}$ \\
\hline Instrumenty konkurowania & $\begin{array}{l}\text { bez zmian lub } \\
\text { mała zmiana }\end{array}$ & $\begin{array}{l}\text { duże zmiany } \\
\text { lub nowe } \\
\text { instrumenty }\end{array}$ \\
\hline $\begin{array}{l}\text { Wartości dla } \\
\text { przedsiębiorstwa }\end{array}$ & bez zmian & $\begin{array}{l}\text { nowe dodatkowe } \\
\text { wartości } \\
\text { dla } \\
\text { przedsiębiorstwa }\end{array}$ \\
\hline $\begin{array}{l}\text { Związki wewnętrzne: } \\
\text { - przynależności celowej } \\
\text { - kompatybilności } \\
\text { - przystawania } \\
\text { - zgodności wzajemnej } \\
\text { - zgodności funkcjonalnej }\end{array}$ & $\begin{array}{l}\text { bez zmian lub } \\
\text { mała zmiana }\end{array}$ & $\begin{array}{l}\text { nowe powiązania } \\
\text { wewnętrzne }\end{array}$ \\
\hline $\begin{array}{l}\text { Związki zewnętrzne: } \\
\text { - zgodności celowej } \\
\text { - podobieństwa } \\
\text { - przyczynowo-skutkowe }\end{array}$ & $\begin{array}{l}\text { bez zmian lub } \\
\text { mała zmiana }\end{array}$ & $\begin{array}{l}\text { duże zmiany } \\
\text { lub nowe } \\
\text { powiązania } \\
\text { zewnętrzne }\end{array}$ \\
\hline
\end{tabular}

Źródło: opracowanie własne.

W procesie odnowy modelu biznesu można wyróżnić następujące fazy:

- Pierwsza to odnowa wartości dla klienta - to jest początkowy i najważniejszy etap rewitalizacji. Tutaj wszystko się zaczyna. Rewitalizacja tych wartości to jest przedmiot, z którym przedsiębiorstwo wyjdzie na rynek. Będą one (wartości) poprzez marketing komunikowane klientom.

- Druga to rewitalizacja kompetencji, zasobów i łańcucha tworzenia wartości - musi podołać konieczności wytwarzania nowych wartości. Ich rozwój jest krytyczny dla nowych wartości. Ponadto w łańcuchu wartości w celu wytworzenia nowych wartości potrzebne jest nawiązanie nowych związków wewnętrznych.

- Trzecia to rekonfiguracja kanałów dystrybucji - podniesienie znaczenia nowych wartości może nastąpić poprzez dostarczanie ich klientom w nowy sposób. Tutaj konieczne jest nawiązanie nowych lub rewitalizacja dotychczasowych relacji zewnętrznych.

- Czwarta to odnowa instrumentów konkurowania - nowe wartości implikują potrzebę zmiany w sposobach konkurowania, zwłaszcza po to, aby uzyskać zwrot nakładów poniesionych na wygenerowanie nowych wartości. Osiąg- nięcie tego wymaga niejednokrotnie nawiązania nowych relacji zewnętrznych.

Piąta to rozwinięcie instrumentów przechwytywania wartości dla przedsiębiorstwa - nowe wartości często wymagają zastosowania nowych metod przechwytywania wartości, a w tym ich ochrony przed naśladownictwem. Od jakości tych metod zależy wielkość przechwytywanych wartości. Przedsiębiorstwo podejmuje wysiłek przechwycenia wartości wygenerowanych w każdej grupie. Badacze i menedżerowie często skupiają spojrzenie na wartościach ekonomicznych, a szczególnie finansowych - interesuje ich zysk. Jednak takie postrzeganie wartości przechwytywanych w trakcie prowadzenia biznesu jest nadmiernie ograniczone. Tytułem przykładu można wskazać na markę firmy. Posiada ona tym większe znaczenie, im więcej wiąże się z nią wartości emocjonalnych - to te emocje przechwytuje przedsiębiorstwo. Kolejny przykład to wartości społeczno-etyczne, w których znajduje się ochrona środowiska. Dbanie o to środowisko jest związane z podnoszeniem jakości życia ludzi, na czym każdemu zależy, zatem występuje tutaj przechwytywanie właśnie wartości społeczno-etycznych.

Równolegle do zmian w elementach konstytuujących model biznesu przebiegają zmiany w związkach wewnętrznych i zewnętrznych, spinających powstające zmienione komponenty modelu biznesu w całość. Nowe wartości wymagają stworzenia nowych związków kooperacji i koopetycji.

Efektem odnowy modelu biznesu jest nowy lub odnowiony produkt bądź sposób dostarczania wartości, a to oznacza, że w ocenie klientów występują nowe wartości, np. użytkowe, estetyczne czy emocjonalne.

\section{Uwarunkowania odnowy modelu biznesu}

Powstający model biznesu, np. na początku działalności gospodarczej, jest wypróbowywany, korygowany, rekonfigurowany tak długo, aż osiągnięta efektywność ekonomiczna będzie satysfakcjonująca. Zbudowany model biznesu jest stały w określonym czasie. W razie osiągnięcia wysoce zadowalającej efektywności może wystąpić sytuacja podejmowania przez menedżerów obrony formy działającego modelu biznesu nawet wówczas, gdy zmianie ulegną uwarunkowania zewnętrzne - zmienią się potrzeby klientów. Takie zdarzenia miały miejsce w przypadku Encyklopedii Britannica. Wydawana w formie papierowej encyklopedia ta liczyła kilkadziesiąt tomów. Była postrzegana jako najlepsze wydawnictwo na świecie. Stanowiła pewien benchmark dla innych wydawnictw encyklopedycznych. Model biznesu tego wydawnictwa był tak dobry, że menedżerowie w latach dziewięćdziesiątych XX wieku nie zauważyli, iż potrzeby klientów uległy zmianie w związku z rozwojem informatyki - powstała możliwość emitowania wydawnictw w wersji elektronicznej na płycie CD. Tę możliwość klienci natychmiast zaakceptowali, przemieszczanie się ze zbiorem kilkudziesięciu tomów encyklopedii jest bowiem wysoce utrudnione, natomiast podróżowanie ze zbiorem kilku dyskietek CD jest łatwe. Menedżerowie z wydawnictwa Encyklopedii Britannica przez pewien czas bronili dotychczasowego modelu biznesu, dopiero spadek sprzedaży zmusił ich do zmiany jego formy. 
Opisane tutaj zjawisko S. Voelpel z zespołem. [2005] nazwali „efektem Czerwonej Królowej”.

Wymagania odnowy modelu biznesu są spowodowane wieloma uwarunkowaniami prowadzenia interesów, wśród których R.G. McGrath [2011] wymienia trzy kluczowe: wzrastającą szybkość rekonfiguracji otoczenia, konkurencję w branży oraz ciągłe generowanie lepszej oferty dla klienta. Zmiana uwarunkowań prowadzenia działalności gospodarczej powoduje, że funkcjonowanie modelu biznesu sprawia kłopoty wówczas, gdy przestaje zapewniać satysfakcjonującą efektywność. W takiej sytuacji konieczne jest dokonanie implementujących nowości. W takim świetle ukazane przyczyny innowacyjnych zmian pozwalają wskazać, że innowacyjność modelu biznesu to zagadnienie zmiany jednego, kilku lub wszystkich jego komponentów.

Dotychczas prowadzone badania modeli biznesów obejmowały zagadnienie ich odnowy w sposób fragmentaryczny. Zespół w składzie L. Achtenhagen, L. Melin, L. Naldi [2013] stwierdził, że „chociaż najnowsza literatura o modelach biznesu uznaje potrzebę ich zmiany, to niewiele jest konceptualizacji i empirycznych dowodów na to, co jest potrzebne do jej osiągnięcia”. Opisany wyżej „efekt Czerwonej Królowej”, stanowiska zajęte przez innych badaczy oraz uważna obserwacja biznesu pozwalają wyciągnąć wniosek o potrzebie badań nad zagadnieniem odnowy modelu biznesu.

Na podstawie analizy dostępnej literatury można wskazać, że na zmianę modelu biznesu zwracano uwagę w kontekście innowacji. Zatem ten nurt warto scharakteryzować 7 .

- W podejściu systematyzującym trzy rodzaje innowacji modeli biznesów wyróżnili E. Giesen, S. J. Berman, R. Bell oraz A. Blitz [2007]:

a) innowacje modelu łańcucha wartości w branży - ujęte dwojako: pierwsze jest oparte na horyzontalnym przemieszczaniu funkcji pomiędzy różnymi branżami, drugie zaś dotyczy redefinicji istniejącego łańcucha w celu skomasowania lub rozdrobnienia poszczególnych jego ogniw;

b) innowacje modelu dochodu - wykorzystujące rekonfigurację propozycji produktu i osadzonych na nim wartości; ujęto tutaj również zmianę modelu cen;

c) innowacje modelu przedsięwzięcia - ten typ skupia się na przedefiniowaniu ról w branżowym łańcuchu wartości. Ujmuje też redefinicję granic organizacji - rozszerzenie przedsiębiorstwa poprzez sieć pracowników, dostawców, klientów i innych interesariuszy.

Wśród uwarunkowań prowadzących do innowacyjnej zmiany modelu biznesu, zdaniem wymienionych autorów, występuje zrozumienie kontekstu branży, określenie aktualnej pozycji przedsiębiorstwa w branży ( $\mathrm{w}$ tym stopnia przywiązania do branży) oraz wybór właściwego rodzaju innowacji.

- J.W. Mark, C.M. Christensen oraz H. Kagerman [2008] napisali, że osiągnięcie wzrostu z innowacji modelu biznesu jest utrudnione, ponieważ menedżerowie nie wiedzą, kiedy ich model biznesu przestaje 'dobrze grać' i należy wprowadzić nowy. Zatem występuje tutaj tajemnica polegająca na rozpoznaniu potrzeby zmiany modelu biznesu. W tym względzie autorzy formułują cztery pytania, które mają pomóc menedżerom w identyfikacji tej potrzeby: 1. Czy można sformułować ważne propozycje dla klientów? 2. Czy można sformułować wszystkie elementy modelu biznesu tak, że pracując razem, osiągają najwyższą z możliwych skuteczność? 3. Czy można utworzyć nowy model biznesu uwolniony od sprzeczności zawartych w rdzeniu prowadzonego biznesu? 4. Czy nowy model biznesu przeszkodzi konkurentom firmy? Sformułowanie odpowiedzi twierdzących jest wyraźnym wskazaniem do podjęcia prac nad nowym modelem biznesu, który, aby był innowacyjny, musi być nowy nie tylko dla przedsiębiorstwa, ale także dla branży oraz rynku.

M. Langdon [2009], wychodząc z przesłanek twórczej destrukcji J. Schumpetera, napisał o innowacyjności modelu biznesu. W pracy zdefiniował pojęcie innowacyjności jako proces, który odnosi się do nowości rzeczy w aspektach odrębności, oryginalności, użyteczności, a przede wszystkim wartości. Innowacyjność ujął w kontekście atrybutu, procesu i rezultatu. Aby zakwalifikować innowację w biznesie, musi zostać zwiększona wartość w postaci nowych lub ulepszonych funkcji, zmniejszenia kosztów, zmiany ceny, wyższych marż dla sprzedawcy bądź ich kombinacji. W swojej istocie innowacyjne pomysły muszą dotykać tworzenia wyższych wartości dla użytkowników, uzyskiwania cennej przewagi nad konkurentami oraz generowania korzyści ekonomicznych. Wykorzystując sformułowane podejście do innowacji, autor zbudował taksonomię 38 celów innowacji. Ujęto je w siedem grup: struktura firmy, administracja, organizacja, doświadczenie klienta, obsługa klienta, łańcuch dostaw oraz produkt. Wymienione cele tworzą ciekawy potencjał, lecz ujmują świat fragmentarycznie. Patrzenie na części utrudnia objęcie całości, a innowacja powinna obejmować cały system. Autor uważa, że ów system jest ujęty w model biznesu, który formułuje opis działalności jako zintegrowany funkcjonalnie system będący w szczególnej relacji z szerszym rynkiem. Innowacyjność modelu biznesu powinna polegać na przeformułowaniu (w sensie Schumpeterowskim) całego systemu biznesu i opierać się na relacjach przedsiębiorstwa z klientami, tworząc atrakcyjne dla nich środowisko.

Na tle tej pracy można wskazać, że sukces daje pakiet innowacji, które uzupełniają się wzajemnie i tworzą jednolity model biznesu, zapewniający nową lub charakterystycznie inną propozycję wartości.

- D.J. Teece [2010] uważa, że głównym celem modelu biznesu jest kreowanie wartości dla konsumentów. Zadaniem tych wartości jest zwabianie zapłaty, która w pewnej części przemienia się w zysk. Dobry model biznesu powinien

${ }^{6}$ Nazwa nawiązuje do powieści L. Carroll Throught the Looking Glass, w której Czerwona Królowa mówi: jeżeli chcesz pozostać w miejscu, musisz biec szybko, a jeżeli chcesz przemieścić się w inne miejsce, musisz biec jeszcze szybciej.

${ }^{7}$ Przy charakterystyce tego nurtu wykorzystano wyniki pracy zawartej w T. Falencikowski, B. Nogalski, Modele biznesów jako nowy obszar badań w naukach o zarzq̨dzaniu. Pracę skierowano na Konferencję Profesorów GWSH w Katowicach 2014 (w druku). 
być dostosowany do klienta i środowiska biznesu. Kluczowym elementem projektowania modelu biznesu jest przechwycenie wartości z innowacji. Dalej autor wskazuje, że może to nastąpić, gdy innowacje produktowe i technologiczne połączy się z innowacyjnym modelem biznesu i adekwatną strategią. Zabezpieczeniem przed naśladownictwem wdrożonych innowacji mogą być: a) zdolności do budowy wyjątkowych systemów, procesów i zasobów, b) pewien poziom nieprzezroczystości, co zabezpiecza przed podglądaniem stosowanych rozwiązań, c) włączenie mechanizmów kanibalizmu istniejącego u konkurentów sprzedaży, d) zainfekowanie rozwiązaniami psującymi konkurentom ważne relacje biznesowe.

- Od opracowania typologii innowacji pracę rozpoczęli P.A. Koen, H.M.J. Bertels i I.R. Elsum [2011]. Nazwali ją unified business model innovation typology (BMIT). Do jej zbudowania użyli trzech wymiarów: technologii, sieci wartości oraz finansowej stopy zwrotu. Umożliwiło to twórcom wyłonienie dwóch obszarów: innowacji podtrzymujących oraz innowacji modelu biznesu. Przy innowacjach podtrzymujących przedsiębiorstwa często odnoszą sukces, natomiast przy innowacjach modeli biznesu często doznają niepowodzeń. Przy innowacji w modelach biznesu autorzy zwrócili uwagę na konieczność odrębnego podejścia do generowania sieci wartości dla klientów i nie-klientów. Dla obecnych klientów istotne są innowacje podtrzymujące, w celu zaś pozyskania nie-klientów konieczne jest formułowanie całkowicie nowej sieci wartości opartej na nowej technologii, a przez to tworzenie nowych modeli biznesu. Innowacje dla nie-klientów są najtrudniejsze do zrealizowania, ale mają największy potencjał wzrostu. Innowacje modeli biznesów są determinowane przez cel i zakres innowacji wartości oraz technologii i stanowią nową granicę innowacji wychodzącą poza innowacje produktowe.

Ważne jest, aby wprowadzać innowacje w dziedzinach, w których nasi konkurenci nie działają. Kierując się tą myślą, R. Amit i C. Zott [2012] przyjęli, że:

- $\quad$ innowacja modelu biznesu może polegać na dodaniu nowego rodzaju działalności lub zmianie części prowadzonej działalności - bądź łączeniu prowadzonych działalności w nowatorski sposób,

- głównymi sterownikami wartości w modelu biznesu są: nowość, komplementarność, wydajność oraz blokady wewnętrzne,

- w przedsiębiorstwie wybrany model biznesu często nie budzi zastrzeżeń przez długi czas,

- $\quad$ innowacyjny produkt bez innowacyjnego modelu biznesu może nie zapewniać wystarczającej przewagi konkurencyjnej.

Przy przeprowadzaniu innowacji modelu biznesu pomocą może być sformułowanie odpowiedzi na sześć pytań: 1) jakie nowe potrzeby klient będzie adresował do modelu biznesu, 2) jakie nowe działania mogą pomóc zaspokoić potrzeby klientów, 3) jak działania można połączyć w nowatorski sposób, 4) jakie nowatorskie rozwiązania w zakresie zarządzania można znaleźć, 5) w jaki sposób są tworzone wartości dla każdego interesariusza, 6) jakie modele przychodów mogą być przyjęte do uzupełnienia modelu biznesu.

Odnosząc się do wyników prac R. Amita i C. Zotta, warto dodać, że o ile opracowanie odpowiedzi na postawione pytania może pomóc w innowacyjnej rekonfiguracji modelu biznesu, o tyle ich analiza wykazuje, że są one zbyt ogólne, a przez to w rzeczywistym świecie biznesu muszą być doprecyzowane przez menedżerów.

Podsumowując opisany tutaj nurt badań, można uwypuklić niektóre osiągnięcia: naświetlono pojęcie innowacji modelu biznesu, ujęto innowacje rodzajowo, sformułowano ogólne kryteria występowania potrzeby odnowy modelu biznesu, wskazano na wartości dla klientów i nie-klientów stanowiące podstawę innowacyjności modeli biznesu oraz zaznaczono, że sukces daje pakiet innowacji. Te osiągnięcia mogą być wykorzystane do odnowy modelu biznesu w ujęciu bardziej holistycznym.

\section{Podsumowanie}

Przeprowadzone tutaj rozważania pozwalają sformułować wniosek, że do zagadnienia odnowy organizacyjnej polskich przedsiębiorstw należy podejść kompleksowo. Przeprowadzenie takiej odnowy należy oprzeć na składnikach zawartych na rys. 1. Początkiem odnowy modelu biznesu musi być rewitalizacja pomysłu na biznes - to tutaj trzeba wymyślić nowe wartości produktów. Jej zakres będzie decydował o kształcie i głębokości odnowy modelu biznesu, której początkiem musi być innowacyjna rewitalizacja wartości oferowanych klientom. Dalej przez pryzmat tych wartości powinna być dokona innowacyjna zmian poszczególnych komponentów modelu biznesu. W wyniku dotychczasowych prac w zakresie innowacyjności modelu biznesu sformułowano zręby, które mogą być wykorzystane do podejmowania odnowy modeli biznesów. W tym zakresie potrzebne są dalsze wysiłki badawcze w celu większego zapewnienia osiągnięcia sukcesu przy odnowie modeli biznesów.

Kończąc niniejszą pracę nad zagadnieniem odnowy modeli biznesu, warto jeszcze podjąć jedno zagadnienie, tj. wątek semantyczny. Potrzeba ta rysuje się właśnie na tle odnowy. Jeżeli bowiem ze strony naukowców potrzebne są pracę nad strategiczną odnową modelu biznesu, to bez pewnego porządku semantycznego trudno będzie o porozumienie. W literaturze można zauważyć, że pojawia się pojęcie 'model biznesowy' lub jego liczba mnoga 'modele biznesowe'. Otóż moim zdaniem takie sformułowania są błędne, należy bowiem zauważyć, że model dotyczy „rzeczy”. Modeluje się coś, np. dźwig, samochód, samolot, ptaka. Mówi się wówczas o modelu dźwigu, samocho$\mathrm{du}$, samolotu, ptaka. Nikt przecież nie powie, że jest to model dźwigowy, samochodowy, samolotowy czy model ptasi. Wobec tego do rzeczownika 'model' można dołączyć predykat odpowiadający na pytanie - model czego? Natomiast za niewłaściwe należy uznać używanie predykatu odpowiadającego na pytanie - model jaki? W przypadku użycia predykatu odpowiadającego na pytanie 'jaki” należałoby udzielić odpowiedzi np. model dokładny, model mały etc., dookreślając jego cechy. 


\section{Literatura}

Achtenhagen L., Melin L., Naldi L., 2013, Dynamics of business models Strategizing, critical capabilities and activities for sustained value creation, Long Range Planning, vol. 46, s. 427-442.

Agarwal R., Helfat C., 2009, Strategic renewal of organizations, Organization Science, vol. 20, no 2.

Amit R., Zott Ch., 2010, Business model design: An activity system perspective, Long Range Planning, vol. 43.

Amit R., Zott Ch., 2012, Creating value trough business model innovation, MIT Sloan Review, vol. 53, no 3.

Amit R., Zott Ch., 2001, Value creation in e-business, Strategic Management Journal, vol. 22.

Aspara J., Lamberg J.A., Laukia A., Tikkanen H., 2013, Corporate business model transformation and inter-organizational cognition: The case of Nokia, Long Range Planning, vol. 46, s. 459-474.

Baden-Fuller C., Morgan M.S., 2010, Business models as models, Long Range Planning, vol. 43.

Bełz G., 2012, Potencjał dostosowawczy odnowy przedsiębiorstw, Przegląd Organizacji, nr 11.

Brandenburger A.M., Stuart H.W. Jr, 1996,. Value-based business strategy, Journal of Economics \& Management Strategy, vol. 5.

Cyfert Sz., 2012, Systemowy model organizacji: Perspektywa procesów odnowy organizacyjnej, Prace Naukowe Uniwersytetu Ekonomicznego we Wrocławiu, nr 276

Cyfert Sz., Bełz G., Wawrzynek Ł., 2014, Wpływ burzliwości otoczenia na efektywność procesów odnowy organizacyjnej, Organizacja i Kierowanie, $\mathrm{nr} 1 \mathrm{~A}$.

Cyfert Sz., Krzakiewicz K., 2011, Wykorzystanie koncepcji modeli biznesu w zasobowej teorii firmy, [w:] Rozwój szkoły zasobowej zarzadzania strategicznego, red. R. Krupski, Prace Naukowe Wałbrzyskiej Wyższej Szkoły Zarządzania i Przedsiębiorczości, Wałbrzych.

Eyring M.J., Johnson M.W., Nair H., 2012, Nowe modele biznesowe. Sposób na podbój rynków wschodzących, Harvard Business Review Polska, maj.
Falencikowski T., 2014, Koncepcja ciagu zarządzania strategicznego biznesem, Marketing i Rynek, nr 5 (na załączonej płycie CD), s. 325-330.

Falencikowski T., 2013, Spójność modelu biznesu. Koncepcja i pomiar, Wydawnictwo CeDeWu, Warszawa.

Giesen E., Berman S.J., Bell R., Blitz A., 2007, Three ways to successfully innovate your business model, Strategy \& Leadership, vol. 35, no 6.

Hamel G., 2000, Leading the Revolution, Harvard Business School Press, Boston.

Karpacz J., 2011, Determinanty odnowy strategicznej potencjału małych i średnich przedsiębiorstw, Oficyna Wydawnicza Szkoły Głównej Handlowej w Warszawie, Warszawa.

Koen P.A., Bertels H.M. J., Elsum I.R., 2011, The three faces of business model innovation: Challenges for established firms, Research Technology Management, vol. 54, issue 3.

Langdon M., 2008, Business model innovation. The strategy of business breakthroughs, International Journal of Innovation Science, vol. 1, no 4.

Mark J.W., Christensen C.M., Kagerman H., 2008, Reinventing your business model, Harvard Business Review 2008, vol. 86, issue 12.

McGrath R.G., 2011, When your business model is in trouble, An Interview with Rita Gunther McGrath by Sarah Cliffe, Harvard Business Review, January-February.

Nogalski B., 2009, Modele biznesu jako narzędzie reorientacji strategicznej przedsiębiorstw, Master of Business Administration, nr 2.

Osterwalder A., Pigneur Y., 2010, Business Model Generation. John Wiley \& Sons, Inc., Hoboken.

Osterwalder A., Pigneur Y., Tucci C.L., 2005, Clarifying business models: Origins, present, and future of the concept, Communications of AIS, vol. 15.

Teece D.J., 2010, Business models, business strategy and innovation, Long Range Planning, vol. 43.

Voelpel S., Leibold M., Tekie E. von Krogh G.,2005, Escaping the Red Queen effect in competitive strategy: Sense - testing business models, European Management Journal, vol. 23, no 1. 